\title{
ResearchOnline@JCU
}

This is the author-created version of the following work:

Gallo-Cajiao, E., Archibald, C., Friedman, R., Steven, R., Fuller, R.A., Game, E.T., Morrison, T.H., Ritchie, E.G., and UNSPECIFIED (2018) Crowdfunding biodiversity conservation. Conservation Biology, 32 (6) pp. 1462-1435.

Access to this file is available from:

https://researchonline.jcu.edu.au/54370/

Please refer to the original source for the final version of this work:

https://doi.org/10.1111/cobi.13144 


\section{Title: Crowdfunding biodiversity conservation}

Gallo-Cajiao, E. ${ }^{1,2,6}$, Archibald, C. ${ }^{1,2}$, Friedman, R. ${ }^{1}$, Steven, R. ${ }^{1}$, Fuller, R. A. ${ }^{1}$, Game, E. T. ${ }^{1,3}$, Morrison, T. H. ${ }^{4}$, and E. G. Ritchie ${ }^{5}$

${ }^{1}$ School of Biological Sciences, The University of Queensland, St Lucia, QLD 4072, Australia

${ }^{2}$ School of Earth and Environmental Sciences, The University of Queensland, St Lucia, QLD 4072,

Australia

${ }^{3}$ The Nature Conservancy, South Brisbane, QLD 4101, Australia

${ }^{4}$ Australian Research Council Centre of Excellence for Coral Reef Studies, James Cook University,

Townsville, QLD 4811, Australia

${ }^{5}$ School of Life and Environmental Sciences, Centre for Integrative Ecology, Deakin University,

Burwood, VIC 3125, Australia

6Email: e.gallocajiao@uq.edu.au

Running head: Crowdfunding conservation

Keywords: Conservation finance, donations, entrepreneurship, fundraising, philanthropy

Article Impact statement: Crowdfunding for biodiversity conservation has now become a global phenomenon and has potential for expansion.

This article has been accepted for publication and undergone full peer review but has not been through the copyediting, typesetting, pagination and proofreading process, which may lead to differences between this version and the Version of Record. Please cite this article as doi: 10.1111/cobi.13144.

This article is protected by copyright. All rights reserved. 


\section{Abstract}

Raising funds is critical for conserving biodiversity and hence so too is scrutinizing emerging financial mechanisms that might help achieve this goal. In this context, anecdotal evidence indicates crowdfunding is being used to support a variety of activities needed for biodiversity conservation, yet its magnitude and allocation remain largely unknown. We conducted a global analysis to help address this knowledge gap, based on empirical data from conservation-focused projects extracted from crowdfunding platforms. For each project, we determined the funds raised, date, country of implementation, proponent characteristics, activity type, biodiversity realm, and target taxa. We identified 72 relevant platforms and 577 conservation-focused projects that have raised US\$4 790 634 since 2009. Whilst proponents were based in 38 countries, projects were delivered across 80 countries, indicating a potential mechanism of resource mobilization. Proponents were from nongovernmental organizations (35\%), universities (30\%), or were freelancers (26\%). Most projects were for research (40\%), persuasion (31\%), and on-ground actions (21\%). Projects have focused primarily on species $(57.7 \%)$ and terrestrial ecosystems $(20.3 \%)$, and less on marine $(8.8 \%)$ and freshwater ecosystems (3.6\%). Projects have focused on 208 species, including a disproportionate number of threatened bird and mammal species. Crowdfunding for biodiversity conservation has now become a global phenomenon and presents signals for potential expansion, despite possible pitfalls. Opportunities arise from its spatial amplifying effect, steady increase over time, inclusion of Cinderella species, adoption by multiple actors, and funding of a range of activities beyond research. Our study paves the way for further research on key questions, such as campaign success rates, effectiveness, and drivers of adoption. Even though the capital input of crowdfunding so far has been modest compared to other conservation finance mechanisms, its contribution goes beyond funding research and providing capital. Embraced with due care, crowdfunding could potentially become an increasingly important financial mechanism for biodiversity conservation. 


\section{Introduction}

Insufficient funding curtails effective and sustained biodiversity conservation (Bayon et al. 2000; Waldron et al. 2017), prompting the need to improve our understanding of the conservation finance portfolio (Zavaleta et al. 2008). Capital is essential for on-ground actions, environmental campaigning, capacity building and public education, as well as research and monitoring (Jepson \& Ladle 2010). Conservation finance is the range of mechanisms to raise and manage capital for biodiversity conservation (Clark 2007), with traditional examples including tourism-related taxes and fees (Wilkie \& Carpenter 1999), debt-for-nature swaps (Bayon et al. 2000), conservation trust funds (Bonham et al. 2014), payments for ecosystem services (Bishop \& Hill 2014), private foundation grants (Zavaleta et al. 2008), and overseas development assistance (Hickey \& Pimm 2011).

Crowdfunding, a web-based fundraising mechanism, has emerged enabling access to capital for conservation (Buschke 2015; Pimm et al. 2015). Understanding emerging financial mechanisms is important to ensure we realize their full potential, address shortcomings, set priorities for spending, and ensure transparency, accountability, and effective use of resources (Balmford et al. 2003; Coady 2005; Brockington \& Scholfield 2010). Additionally, novel sources of funding require scrutiny as they may signal transformational processes of governance, such as reconfigurations of the role of actors (Lane \& Morrison 2006; Morrison 2017; Wilson et al. 2018). Despite these identified knowledge needs, the contribution of crowdfunding to biodiversity conservation remains poorly understood empirically (Horisch 2015).

The imperative of sourcing funding for conservation and the scant understanding of this novel financial mechanism warrant empirical research. Crowdfunding for conservation has been so far mostly considered tangentially relative to funding research more broadly (Wheat et al. 2013; Pimm 
et al. 2015). This shortcoming is surprising considering the lauded potential of crowdfunding as a mechanism to foster innovation and entrepreneurship in conservation beyond research alone (Buschke 2015). Here, we contribute to addressing this knowledge gap by evaluating empirically the contribution of crowdfunding to biodiversity conservation in relation to its magnitude and allocation, considering research and non-research (e. g., management, outreach, capacity building) activities. We analyze crowdfunding at platform and project levels. For the former, we identify the relevant platforms worldwide, where they are based, and how they have emerged over time. For the latter, we determine who uses crowdfunding, where, for what purpose, and how much capital has been raised through crowdfunding.

\section{Conceptual framework: Definition and context of crowdfunding}

Pooling resources, expertise or efforts, from individuals to accomplish specific actions is a mechanism to enable coordination of social action to attain specific goals. This phenomenon has historically been a feature of human society, and perhaps one of the best-known early examples of crowdfunding was the construction of the pedestal of the Statue of Liberty (Gray \& Zhang 2017). However, more recently this phenomenon has become amplified and reshaped through the internet as a Web 2.0 phenomenon, known as online crowdfunding (Bouncken et al. 2015; Beck et al. 2016). Generally, crowdfunding is the process of fundraising capital from multiple donors, known in this context as 'the crowd', either directly or indirectly. Donors in this context are often individuals, but can also include other actors, such as companies (Macht \& Weatherson 2015; Büscher 2016). Direct crowdfunding is the traditional approach that actors, such as large non-governmental organizations (NGOs), have used to help raise capital for conservation, in which they directly target their constituents to donate money. Conversely, indirect crowdfunding involves the use of an intermediary, a crowdfunding platform in this case, between the fundraiser and the crowd 
(Bouncken et al. 2015). This particular model of online crowdfunding primarily commenced in the arts during the mid-2000s (Agrawal et al. 2013), but has expanded rapidly to other endeavors (Bradford 2012), including conservation (Buschke 2015). We will hereafter refer to this phenomenon simply as crowdfunding, as it is the subject of this study.

The emergence of the intermediary is what makes this phenomenon novel and different, because it possibly reshapes the relationship between fundraisers and the crowd. Crowdfunding involves three actors: the fundraiser, the crowd (i. e., donors), and the intermediary (Bouncken et al. 2015). Crowdfunding platforms, the intermediary in this case, have the potential to reduce the barriers between the fundraiser and the crowd by providing broader reach across space and sectors of society, increasing legitimacy, as well as enabling information sharing (Agrawal et al. 2011; Wheat et al. 2013; Frydrych et al. 2014). Crowdfunding platforms create an opportunity not only for fundraisers but also for the crowd. Through the power of the internet, individual donors can easily support local causes in distant locations (Agrawal et al. 2011). Within web-based indirect crowdfunding, there are mainly four models with some degree of overlap: donation-based, rewardbased, loan-based, and equity-based (Bouncken et al. 2015). The donation and reward models involve the transfer of funds from a donor to a fundraiser. These two models are where philanthropic crowdfunding fits, which is the subject of this paper.

Crowdfunding may also be considered as a signal of change in the agency of actors (Dellas et al. 2011) and locus of authority, a process affecting many aspects of global environmental governance, including rule-making (Pattberg \& Widerberg 2015). Conservation finance is an integral component of environmental governance, as it facilitates the execution of actions guided by norms, rules, and principles. Environmental governance takes place in a tridimensional space, where the state, the society, and the private sector interact with one another (Lemos \& Agrawal 2006). In this context, 
we can conceive crowdfunding as a potential transformative phenomenon where the role of actors that have traditionally provided funding shifts, facilitated by the rise of a new actor, the intermediary platforms. Some have considered crowdfunding as a signal of state retreat from their responsibilities and failing financial markets (Gossel et al. 2016); however, in the absence of robust empirical evidence the drivers of the emergence of crowdfunding for conservation remain unclear. It is unknown to what extent crowdfunding is actually increasing the total funds for conservation or whether it is just redistributing the contribution from the same set of actors. Furthermore, crowdfunding may be enabling the emergence of actors that previously did not have agency, not just for those who seek funds but also those that provide funds.

\section{Methods}

We conducted an exhaustive global survey of relevant crowdfunding platforms and projects with a focus on biodiversity conservation using a mixed methods approach. Relevant crowdfunding platforms were defined using project categories (e.g., environmental) as proxies that could be indicative of biodiversity-focused projects. In turn, biodiversity-focused projects were defined as those with an explicit, or direct, biodiversity, or ecological, dimension with a conservation outcome orientation, at least aspirationally, including both research and non-research activities. We based our survey on authoritative directories of crowdfunding platforms (Supporting Information 1), from which we selected platforms according to project categories, used as a proxy for potentially relevant projects (Supporting Information 2). Subsequently, we searched throughout all selected platforms for successful and completed projects with an explicit biodiversity conservation goal. Using document and thematic analysis (Bowen 2009; Supporting Information 3), we extracted data from all projects for the following variables: closing date, amount of funds sought, amount of funds raised, country of project, country of proponent, type of proponent, scale of proponent, theme, sub- 
theme, type, sub-type, focus species, and conservation status of focus species. Theme represents the focus of projects on biodiversity realms, on either ecosystems or species, whereas type refers to the kind of activity delivered. We analyzed our dataset focusing on temporal and spatial patterns of crowdfunding used for conservation, as well as on an array of biodiversity realms, various conservation activities, conservation priorities, and funds raised (further details on methods: Supporting Information 4).

\section{Results}

Relevant crowdfunding platforms and conservation-focused projects have emerged within the last 15 years, with a geographically skewed distribution. We identified 72 relevant crowdfunding platforms, which represent all continents except Antarctica (Fig. 1). These platforms are based in 28 countries, primarily western high-income economies (79\% of platforms). Countries in the upper quartile of the frequency distribution (>3 platforms) include the USA, UK, Spain, Brazil, Canada, and India. Crowdfunding platforms have emerged since 2002 , with $50 \%$ by 2011 , after a steep increase since the late 2000s. The earliest conservation-focused project recorded was from 2009 , with $50 \%$ of projects having emerged by 2015 after a steep increase since the early 2010s (Supporting Information 5). Regarding the number of projects per platform, $37.5 \%$ of them have no projects that met our criteria, whereas $23.6 \%$ of platforms, those in the upper quartile of the frequency distribution ( $>6$ projects), contain $89.7 \%$ of all projects found. In total, 577 conservation-focused projects on crowdfunding platforms have raised US\$4 790634 , with a mean project value of US\$8302 and a median of US\$3991, indicating a skewed distribution (min=US\$84; $\max =$ US\$561 276; Supporting Information 6).

This article is protected by copyright. All rights reserved. 
Whilst project proponents represent a wide range of actors and were based in 38 countries, projects were delivered across 80 countries (Fig. 1, Fig. 2). Projects were primarily proposed by people affiliated with NGOs (35\%), universities (30\%), as well as by freelancers $(26 \%)$. Furthermore, most of the NGOs considered operate at the subnational level (66.5\%), with only a small number operating at an international level (14.2\%; Fig. 2). Nine countries (Australia, Brazil, Canada, France, Japan, Russia, Spain, UK, and the USA), primarily with high and upper-middle income economies, hosted the proponents for $83 \%$ of all projects. These countries account for the upper quartile of the frequency distribution. Proponents of one third of all projects were based in the USA. Conversely, ten countries, mostly with lower income economies, each hosted the proponent for only a single project. The majority of projects (95.8\%) were delivered within single countries, and only a small proportion (4.2\%) had a spatial scope spanning more than one country. Projects within single countries were primarily delivered in the USA (19\%), Australia (12.4\%), and Spain (10.3\%). However, other countries with lower income economies included Brazil (4\%), Indonesia (4\%), and Mexico (3.8\%).

The increasing geographic spread from where platforms are based, to where proponents are hosted, and where projects are ultimately delivered signals a global-scale mechanism of flows (Fig. 1). A large proportion of projects (62.5\%) completely occurred within a single country across platform, proponent, and project. However, one third of projects (31.2\%) were delivered in countries different from where their proponents were based, and the proponents of $12.8 \%$ of projects were based in a different country to their corresponding platform. Consequently, there are international project outflows and inflows. The USA, UK, and Australia present the highest outflow, whereas Indonesia, South Africa, Costa Rica, and Mexico present the highest inflow (Fig. 3). In total, 16 countries present outflows whereas 60 present inflows, denoting an asymmetric relationship. The majority of flows 
(85\%) occurred from countries with high-income economies to countries with lower income economies.

Crowdfunding has funded an array of conservation-related activities focusing on various biodiversity realms (Fig. 2, Supporting Information 7). The majority of projects focused on research (40\%), followed by persuasion (31\%), on-ground actions (21\%), and capacity building activities (7\%). Within research, projects focused on autecology $(29.4 \%)$, threats to biodiversity $(23.8 \%)$, biological surveys (18\%), and fewer on evaluating conservation interventions (4.3\%). Most projects related to persuasion focused on awareness raising (87\%), whereas on-ground actions generally involved vegetation/habitat management (36\%) or building animal/plant facilities (22\%). Over half of projects focused on species $(57.7 \%)$, followed by terrestrial ecosystems $(20.3 \%)$, whereas marine $(8.8 \%)$ and freshwater (3.6\%) ecosystems received the least attention. For terrestrial ecosystems, forests received the most attention (67.5\%) and deserts the least (0.8\%). For marine ecosystems, coastal $(31 \%)$ and coral (16\%) ecosystems have the greatest representation and kelp forest ecosystems the least (1.9\%). Furthermore, river ecosystems presented the highest proportion (47.6\%) of freshwater focused projects and wetland ecosystems the lowest (14\%).

More than one third of projects (39\%) focused explicitly on one or more species, covering between them 208 species, spanning various taxonomic groups (Fig. 2, Supporting Information 7). Mammals (43\%) and birds (25\%) were the most well represented and amphibians the least (2\%). When considering the number of projects per species, the gray wolf (Canis lupus), loggerhead turtle (Caretta caretta), African elephant (Loxodonta africana), black rhinoceros (Diceros bicornis), Bornean orangutan (Pongo pygmaeus), and green turtle (Chelonia mydas) have the highest frequency ( $\geq 5$ projects per species). Conversely, $80.7 \%$ of species had only one project. Focus species included by projects were as often considered to be of least concern (40.8\%) as they were threatened $(39.4 \%)$, 
and in turn the latter was almost equally distributed across threatened categories (critically endangered, endangered, vulnerable; IUCN 2017; Supporting Information 7). Moreover, when each taxon is considered individually, mammals $\left(\chi^{2}=21.1898 ; p<.00001 ; p<.01\right)$ and birds $\left(\chi^{2}=10.4541\right.$; $p=.001224 ; p<.01)$ present a disproportionate number of threatened species when compared to the expected values based on all their species under the global IUCN red list (IUCN 2017).

\section{Discussion}

Our study indicates that crowdfunding for biodiversity conservation is a burgeoning and now global phenomenon. Crowdfunding primarily originates from countries with high income and emerging economies. This financial mechanism is likely enabling resource mobilization across national borders reaching lower income countries, has funded an array of conservation activities, and has been used across multiple ecosystems and taxa, including threatened species. The capital input from crowdfunding so far has been modest compared to other sources of conservation finance. Nevertheless, our results indicate further potential within specific areas, as well as impact beyond funding research and providing capital.

Crowdfunding appears to geographically expand access to capital for conservation. Platforms and project proponents are concentrated in fewer countries than where projects are delivered. Consequently, crowdfunding as an intermediary platform, which is the subject of our study, has a spatial amplifying effect. By spatial amplifying effect, we mean that crowdfunding enables an expansion of the number of countries in which funds are available for conservation. This can have profound implications, as crowdfunding may be allowing access to capital in places where other sources of funding are scarcer (Gray \& Zhang 2017). Although we did not determine the actual provenance of individual donations for each project, other research suggests that donors in the 
vicinity of proponents can play an important role (Agrawal et al. 2011; Dahlhausen et al. 2016).

Therefore, it is likely that at least a proportion of capital, which remains unquantified, of the projects whose proponent are based in a different country to where project are delivered, are flowing across national borders. The pattern of international flows of crowdfunding projects mirrors that reported for international aid for conservation, in which financial flows occur from high-income countries to lower income countries (Miller et al. 2013). Moreover, at least in some cases, those flows of crowdfunding projects are occurring to countries where biodiversity conservation priorities are high and conservation remains underfunded, such as Indonesia (Lee \& Jetz 2008; Waldron et al. 2013; Wilson et al. 2016).

Crowdfunding may be expanding the agency of some actors that have limited fund raising capacity. We found that NGOs, universities, and freelancers most often use crowdfunding for conservation. Among NGOs, this financial mechanism is primarily enabling those operating at a subnational level to access capital. Subnational NGOs frequently have low fundraising capacity and are vulnerable to changes in the conservation finance portfolio (Coady 2005; Parks 2008; Armsworth et al. 2012). Likewise, freelancers, which are individuals without any official institutional affiliation, accounted for one-quarter of proponents. Hence, crowdfunding platforms may not be just providing a logistical mechanism for raising funds, but also for legitimation. The participation of subnational NGOs and freelancers could potentially increase democracy in conservation by pluralizing discourses and practice. This becomes paramount when considering a large proportion of NGOs operate at a subnational level, at least, in particular countries, such as the USA (Armsworth et al. 2012).

We have systematically revealed the use of crowdfunding for broad-based conservation and across biodiversity realms. Research activities have received the most attention; however, persuasion and on-ground actions have also frequently featured. Furthermore, we unpack those activities more 
specifically for the first time, providing additional insights into the use of crowdfunding for conservation. For instance, we discovered that most research projects have focused on autecology and threats, while most persuasion projects have targeted raising awareness. Even though crowdfunding projects have targeted various biodiversity realms, half of the projects have focused on species, particularly mammals and birds, which could be potentially associated with their broader appeal to both fundraisers and donors (Clucas et al. 2008). Those species represent a disproportionate number of globally threatened species of mammals and birds, such as the Javan slow loris (Nycticebus javanicus) and orange-bellied parrot (Neophema chrysogaster), both critically endangered (IUCN 2017). While some projects have focused on well-known and charismatic species, other projects have explicitly focused on less popular species too, such as the fishing cat (Prionailurus viverrinus) and Wolffsohn's viscacha (Lagidium wolffsohni), which could be considered as Cinderella species for being currently overlooked but having the potential to garner public support (Smith et al. 2012). These findings may indicate how crowdfunding could potentially increase the conservation-funding base, as well as make it more resilient through diversification.

In general, the financial contribution of crowdfunding to conservation appears relatively small, but it could fill critical gaps. The total contribution of crowdfunding to conservation seems minor ( $\approx$ US\$4.8 million) when compared with the annual income of conservation NGOs in the USA alone (US\$6.32 billion; Armsworth et al. 2012), estimated budgets for expanding and managing global networks of protected areas (US\$57.8 billion; McCarthy et al. 2012), annual expenditure of the World Bank for supporting national parks in developing countries (US\$275 million; Hickey \& Pimm 2011), and allocation to conservation through international aid (US\$18.55 billion; Miller et al. 2013). However, based on the experience of crowdfunding users for conducting research, as well as studies on crowdfunding use in the business sector, this novel mechanism has the potential to complement existing financial mechanisms. For instance, crowdfunding may be providing seed capital that can 
leverage larger funding sources (Feder 2013; Makris 2015; Sorenson et al. 2015; Dahlhausen et al. 2016), bridging funding gaps between project cycles, supporting specific tasks as part of larger initiatives, covering shortfalls left by the erosion of traditional funding sources, lowering access barriers given increased competition for traditional funding sources (Bakker et al. 2010; Kaplan 2013; Marshall 2013), and funding initiatives that would unlikely be funded otherwise (Dahlhausen et al. 2016). Crowdfunding may also overcome bureaucratic challenges associated with other funding sources (Kaplan 2013), as well as expedite the fundraising process at times of urgency when extinction of species appears imminent (Martin et al. 2012).

There are also non-financial advantages and possible pitfalls of using crowdfunding for conservation, which need further consideration. Whilst we did not conduct an explicit empirical analysis of pros and cons of crowdfunding use for conservation, it is important to interpret our results critically. For instance, this mechanism could be a source of innovative ideas with potential for diffusion, as proponents are not constrained by priorities set by traditional funding agencies. Additionally, crowdfunding enables greater engagement with the public throughout the entire project cycle (Kaplan 2013; Wheat et al. 2013). These personal connections are not just vital for meeting fund raising goals, but also create opportunities for education enhancing conservation awareness (Marshall 2013; Wheat et al. 2013; Dahlhausen et al. 2016). As crowdfunding is a non-market-based mechanism drawing funds primarily from individuals, funding is less likely to be affected by market forces and vested interests. By contrast, this financial mechanism has potential drawbacks due to uncertainty about the effectiveness of funded actions (Buschke 2015), latency for fueling discourses leading to erosion of government funding (Brabham 2017), disjunctures between expectations and outcomes (Büscher 2016), and lack of coordination in setting priorities for allocating funds. 
Our study focuses on the extent and allocation of capital from crowdfunding for conservation, paving the way for further research. For instance, we did not evaluate success rates of projects and the variables that explain them, including donor motivations. Some of the biases we discovered, such as the emphasis on species or terrestrial ecosystems, should be explored as it is unclear to what extent they are given by success rates or by the preference of proponents. Our focus in this study was on strict-sense conservation funding. Hence, further research on mixed conservation funding that also includes other societal goals, such as poverty alleviation, would expand on the additional contribution of crowdfunding and possible interactions with other issue areas, including synergies and trade-offs. Comparative studies focusing on the performance of funding allocation to achieve conservation goals between strict-sense and mixed funding from crowdfunding would contribute to the broader question of funding effectiveness (Miller 2014; Waldron et al. 2017). Additionally, what explains the emergence and uptake of crowdfunding for conservation remains an empirical area of enquiry. Addressing these, and additional, questions would assist advancing conservation goals through further crowdfunding adoption, but would require different methodological approaches than the one we adopted here.

\section{Conclusions}

Crowdfunding is a novel financial mechanism contributing to biodiversity conservation globally and has further potential. Opportunities arise from its spatial amplifying effect, steady temporal increase, inclusion of Cinderella species, adoption by multiple actors, and funding of a suite of activities beyond research. However, as an emerging phenomenon, is crowdfunding just another conservation fad that may not thrive long-term (Redford et al. 2013)? This remains to be determined. More importantly, we stress that while it is innovative and appealing; crowdfunding should be used with consideration of its advantages and challenges that will vary in relation to 
specific conservation objectives and proponent capacity within the context of the broader conservation finance portfolio. Further research on the use of crowdfunding for biodiversity conservation focusing on key topics, such as success rates, effectiveness, uptake, and raising the public profile of environmental issues, would contribute to the conservation finance (Zavaleta et al. 2008), environmental governance (Lemos \& Agrawal 2006), and crowdfunding literature (Gossel et al. 2016), as well as facilitate the achievement of conservation goals. Embraced with due care, crowdfunding has the potential to become an increasingly important financial mechanism for biodiversity conservation.

\section{Acknowledgements}

We are grateful to all the crowdfunding platforms considered in this study, as well as to J. O'Donnell, M. Holden, D. Biggs, B. Woodworth, and two anonymous reviewers for providing insights into the manuscript. EGC, CA, and RF are supported through a top-up scholarship from the Australian Research Council Centre of Excellence for Environmental Decisions.

\section{Supporting Information}

Supporting Information 1: directories of crowdfunding platforms

Supporting Information 2: metadata on crowdfunding platforms

Supporting Information 3: coding framework for thematic analysis of projects

Supporting Information 4: further details on methods

This article is protected by copyright. All rights reserved. 
Supporting Information 5: temporal emergence of platforms and projects

Supporting Information 6: full dataset of conservation-focused projects supported through crowdfunding

Supporting Information 7: further data on theme, sub-theme, type, sub-type, and focus taxa

\section{Literature Cited}

Agrawal, A., C. Catalini, and A. Goldfarb. 2011. The geography of crowdfunding. Working paper 16820. National Bureau of Economic Research, Cambridge, MA.

Agrawal, A., C. Catalini, and A. Goldfarb. 2013. The simple economics of crowdfunding, innovation policy and the economy. Working paper 19133. National Bureau of Economic Research, Cambridge, MA.

Armsworth, P. R., I. S. Fishburn, Z. G. Davies, J. Gilbert, N. Leaver, and K. J. Gaston. 2012. The size, concentration, and growth of biodiversity-conservation nonprofits. Bioscience 62:271-281.

Bakker, V. J., J. K. Baum, J. F. Brodie, A. K. Salomon, B. G. Dickson, H. K. Gibbs, O. P. Jensen, and P. B. McIntryre. 2010. The changing landscape of conservation science funding in the United States.

Conservation Letters 3:435-444.

This article is protected by copyright. All rights reserved. 
Balmford, A., K. J. Gaston, S. Blyth, A. James, and V. Kapos. 2003. Global variation in terrestrial conservation costs, conservation benefits, and unmet conservation needs. Proceedings of the National Academy of Sciences 100:1046-50.

Bayon, R., J. S. Lovink, and W. J. Veening. 2000. Financing biodiversity conservation. Technical Papers Series. Inter-American Development Bank, Sustainable Development Department, Washington, DC.

Beck, R., D. Brüntje, A. Dardour, O. Gajda, D. Marom, I. Pais, and A. Will. 2016. Introduction. Pages 1-4 in D. Brüntje and O. Gajda, editors. Crowdfunding in Europe, FGF studies in small business and entrepreneurship. Springer International, Switzerland.

Bishop, J., and C. Hill. 2014. Global biodiversity finance: the case of international payments for ecosystem services. Edward Elgar Publishing Limited, Cheltenham, UK.

Bonham, C., M. K. Steininger, M. Mcgreevey, C. Stone, T. Wright, and C. Cano. 2014. Conservation trust funds, protected area management effectiveness and conservation outcomes: lessons from the global conservation fund. Parks 20:89-100.

Bouncken R. B., M. Komorek, and S. Kraus. 2015. Crowdfunding: the current state of research. International Business \& Economics Research Journal 14:407-417.

Bowen, A. G. 2009. Document analysis as a qualitative research method. Qualitative Research Journal 9:27-40.

This article is protected by copyright. All rights reserved. 
Brabham, D. C. 2017. How crowdfunding discourse threatens public arts. New Media \& Society 19:983-999.

Bradford, C. S. 2012. Crowdfunding and the federal securities law. Columbia Business Law Review $1: 3-148$

Brockington, D., and K. Scholfield. 2010. Expenditure by conservation nongovernmental organizations in sub-Saharan Africa. Conservation Letters 3:106-113.

Büscher, B. 2016. Conservation and development 2.0: Intensifications and disjunctures in the politics of online 'do-good' platforms. Geoforum 79:163-173.

Buschke, F. T. 2015. The startup culture of conservation entrepreneurship. Conservation Biology 29:300-302.

Clark, S. 2007. A field guide to conservation finance. Island Press, Washington, DC.

Clucas, B., K. McHugh, and T. Caro. 2008. Flagship species on covers of US conservation and nature magazines. Biodiversity and Conservation 17:1517-1528.

Coady, P. 2005. Conservation finance viewed as a system: tackling the financial challenge. Pages 2236 in J. N. Levitt, editor. From Walden to Wall Street, frontiers of conservation finance. Island Press, Washington, DC. 
Dahlhausen, K., B. L. Krebs, J. V. Watters, and H. H. Ganz. 2016. Crowdfunding campaigns help researchers launch projects and generate outreach. Journal of Microbiology \& Biology Education 17:32-37.

Dellas, E., P. Pattberg, and M. Betsill. 2011. Agency in earth system governance: refining a research agenda. International Environmental Agreements: Politics, Law and Economics 11:85-98.

Feder, T. 2013. Scientists experiment with crowdfunding. Physics Today 66:23-24.

Frydrych, D, A. Bock, T. Kinder, and B. Koeck. 2014. Exploring entrepreneurial legitimacy in rewardbased crowdfunding. Venture Capital 16:247-269.

Gossel, B. M., D. Brüntje, and A. Will. 2016. Crowd and society: outlining a research programme on the societal relevance and the potential of crowdfunding. Pages 55-67 in D. Brüntje and O. Gajda, editors. Crowdfunding in Europe, FGF studies in small business and entrepreneurship. Springer International, Switzerland.

Gray, M., and B. Zhang. 2017. Crowdfunding: understanding diversity. Pages 580-609 in R. Martin R and J. Pollard, editors. Handbook on the geographies of money and finance. Edward Elgar Publishing, Cheltenham, UK.

Hickey, V., and S. L. Pimm. 2011. How the World Bank funds protected areas. Conservation Letters 4:269-277. 
Horisch, J. 2015. Crowdfunding for environmental ventures: An empirical analysis of the influence of environmental orientation on the success of crowdfunding initiatives. Journal of Cleaner Production 107:636-645.

IUCN. 2017. The IUCN Red List of Threatened Species. www.iucnredlist.org (accessed August 2017).

Jepson, P., and Ladle R. 2010. Conservation, a beginner's guide. Oneworld, Oxford, UK.

Kaplan K. 2013. Cash on demand. Nature 497:147-149.

Lane, M. B., and T. H. Morrison. 2006. Public interest or private agenda? A meditation on the role of NGOs in environmental policy and management in Australia. Journal of Rural Studies 22:232-242.

Lee, T. M., and W. Jetz. 2008. Future battlegrounds for conservation under global change.

Proceedings of the Royal Society B: Biological Sciences 275:1261-1270.

Lemos, M. C., and A. Agrawal. 2006. Environmental governance. Annual Review of Environment and Resources 31:297-325.

Macht, S. A., and J. Weatherson. 2015. Academic research on crowdfunders: what's been done and what's to come? Strategic Change 24:191-205.

Makris, G. C. 2015. Crowdfunding: from startup businesses to startup science. British Medical Journal 350:h18.

This article is protected by copyright. All rights reserved. 
Marshall, J. 2013. Kickstart your research. Proceedings of the National Academy of Science 110:4857-4859.

Martin, T. G., S. Nally, A. A. Burbidge, S. Arnall, S. T. Garnett, M. W. Hayward, L. F. Lumsden, P. Menkhorst, E. McDonald-Madden, and H. P. Possingham. 2012. Acting fast helps avoid extinction. Conservation Letters 5:274-280.

McCarthy, D. P. , P. F. Donald, J. P. W. Scharlemann, G. M. Buchanan, A. Balmford, J. M. H. Green, L. A. Bennun, N. D. Burgess, L. D. C. Fishpool, S. T. Garnett, D. L. Leonard, R. F. Maloney, P. Morling, H. M. Schaefer, A. Symes, D. A. Wiedenfeld, and S. H. M. Butchart. 2012. Financial costs of meeting global current spending and unmet needs. Science 338:946-949.

Miller, D. C., A. Agrawal, and J. T. Roberts. 2013. Biodiversity, governance, and the allocation of international aid for conservation. Conservation Letters 6:12-20.

Miller, D. C. 2014. Explaining global patterns of international aid for linked biodiversity conservation and development. World Development 59:341-359.

Morrison, T. H. 2017. Evolving polycentric governance of the Great Barrier Reef. Proceedings of the National Academy of Sciences, 114:E3013-E3021.

Parks, T. 2008. The rise and fall of donor funding for advocacy NGOs: understanding the impact. Development in Practice 18:213-222. 
Pattberg, P., and O. Widerberg. 2015. Theorising global environmental governance: key findings and future questions. Journal of International Studies 43:684-705.

Pimm, S. L., S. Alibhai, R. Bergl, A. Dehgan, C. Giri, Z. Jewell, L. Joppa, R. Kays, and S. Loarie. 2015. Emerging technologies to conserve biodiversity. Trends in Ecology and Evolution 30:685-696.

Redford, K. H., C. Padoch, and T. Sunderland. 2013. Fads, funding, and forgetting in three decades of conservation. Conservation Biology 27:437-438.

Smith, R. J., D. Veríssimo, N. J. B. Isaac, and K. E. Jones. 2012. Identifying Cinderella species: Uncovering mammals with conservation flagship appeal. Conservation Letters 5:205-212.

Sorenson, B. O., V. Assenova, G. Li, and J. Boada. 2015. Expand innovation finance via crowdfunding. Science 354:1526-1528.

Waldron, A., A. Mooers, D. C. Miller, N. Nibbelink, D. Redding, T. S. Kuhn, J. T. Roberts, and J. L. Gittleman. 2013. Targeting global conservation funding to limit immediate biodiversity declines. Proceedings of the National Academy of Scieces 110:12144-12148.

Waldron, A., D. C. Miller, D. Redding, A. Mooers, T. S. Kuhn, N. Nibbelink, J. T. Roberts, J. A. Tobias, and J. L. Gittleman. 2017. Reductions in global biodiversity loss predicted from conservation spending. Nature 551:364-367.

Wheat, R. E., Y. Wang, J. E. Byrnes, and J. Ranganathan. 2013. Raising money for scientific research through crowdfunding. Trends in Ecology and Evolution 28:71-72. 
Wilkie, D. S. and J. F. Carpenter. 1999. Can nature tourism help finance protected areas in the Congo

Basin? Oryx 33:333-339.

Wilson, K. A., N. A. Auerbach, K. Sam, A. G. Magini, A. St. L. Moss, S. D. Langhans, S. Budiharta, D.

Terzano, and E. Meijaard. 2016. Conservation research is not happening where it is most needed.

PLoS Biology 14:1-5.

Wilson, C., T.H. Morrison, J. Everingham and J. McCarthy. 2018. Capture and crush: Gas companies in

the fracking dispute and deliberative depoliticization. Geoforum 92:106-116.

Zavaleta, E., D. C. Miller, N. Salafsky, E. Fleishman, M. Webster, B. Gold, D. Hulse, M. Rowen, G.

Tabor, and J. Vanderryn. 2008. Enhancing the engagement of U.S. private foundations with

conservation science. Conservation Biology 22:1477-1484.

This article is protected by copyright. All rights reserved. 


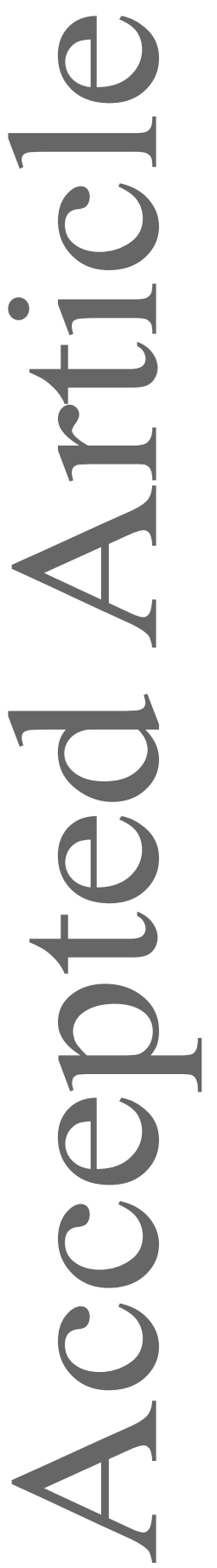

a)

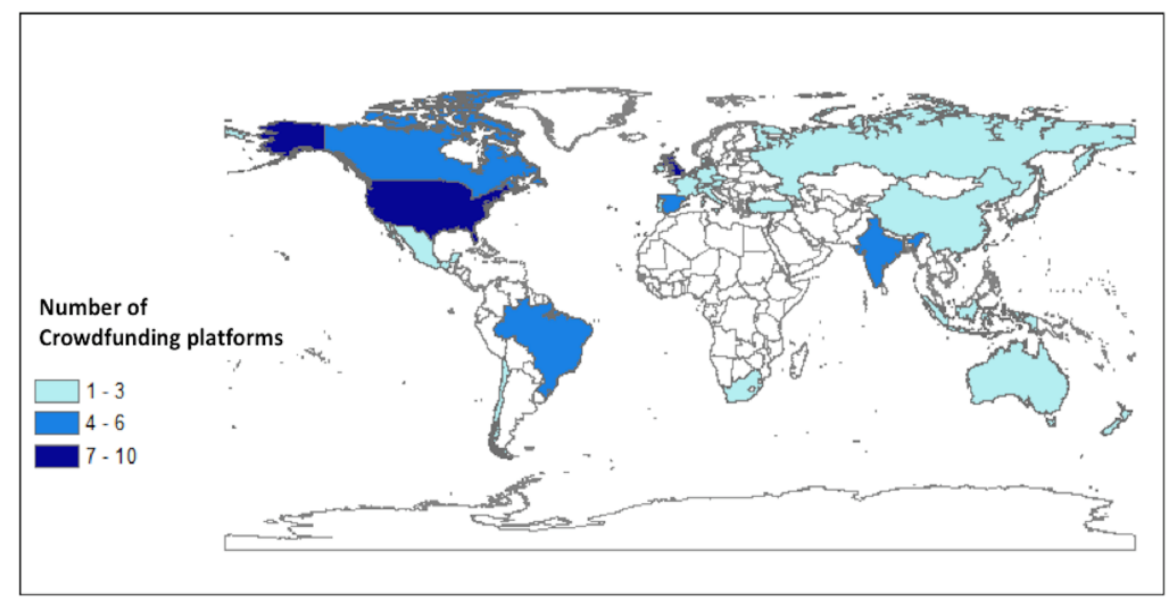

b)

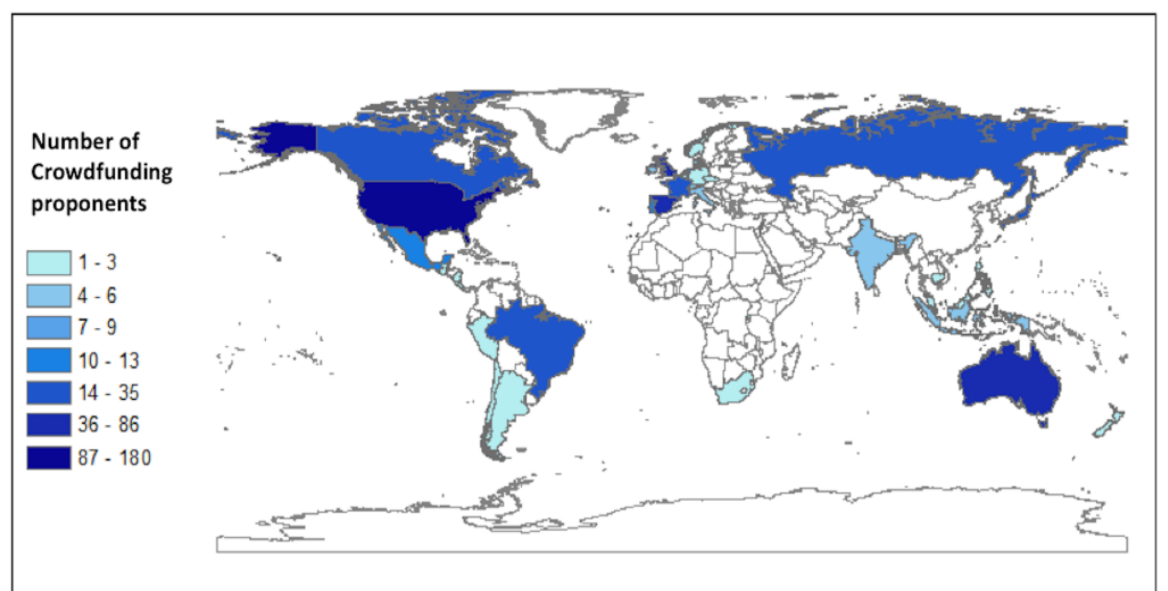

c)

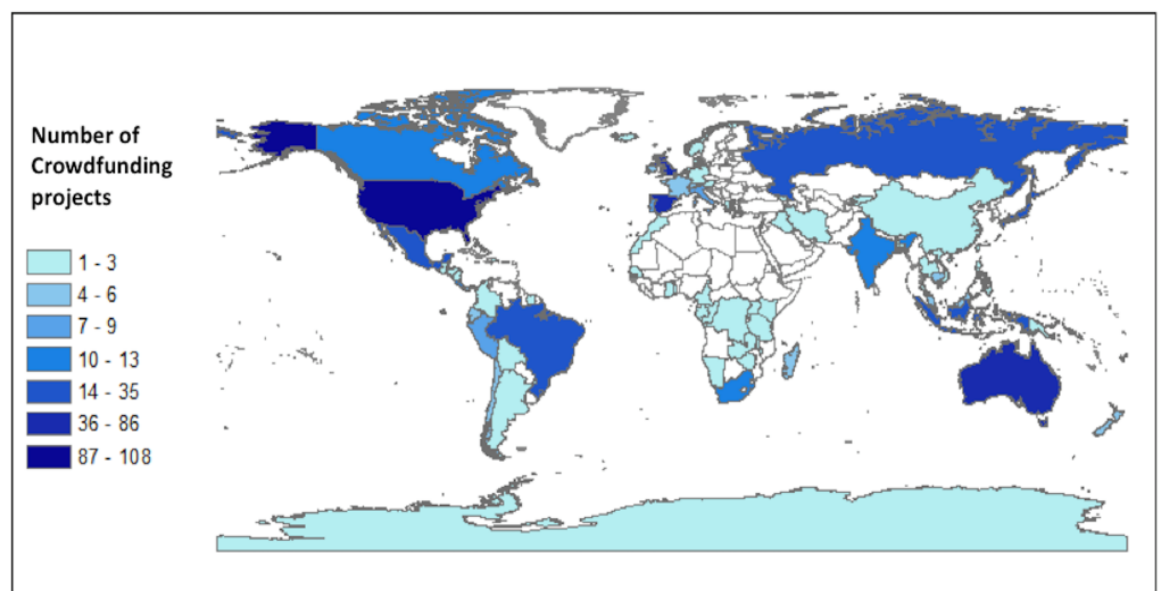

Figure 1. Global distribution of crowdfunding for biodiversity conservation: (a) countries where relevant platforms are based, (b) countries where proponents of projects are hosted, and (c) countries where projects are delivered.

This article is protected by copyright. All rights reserved. 


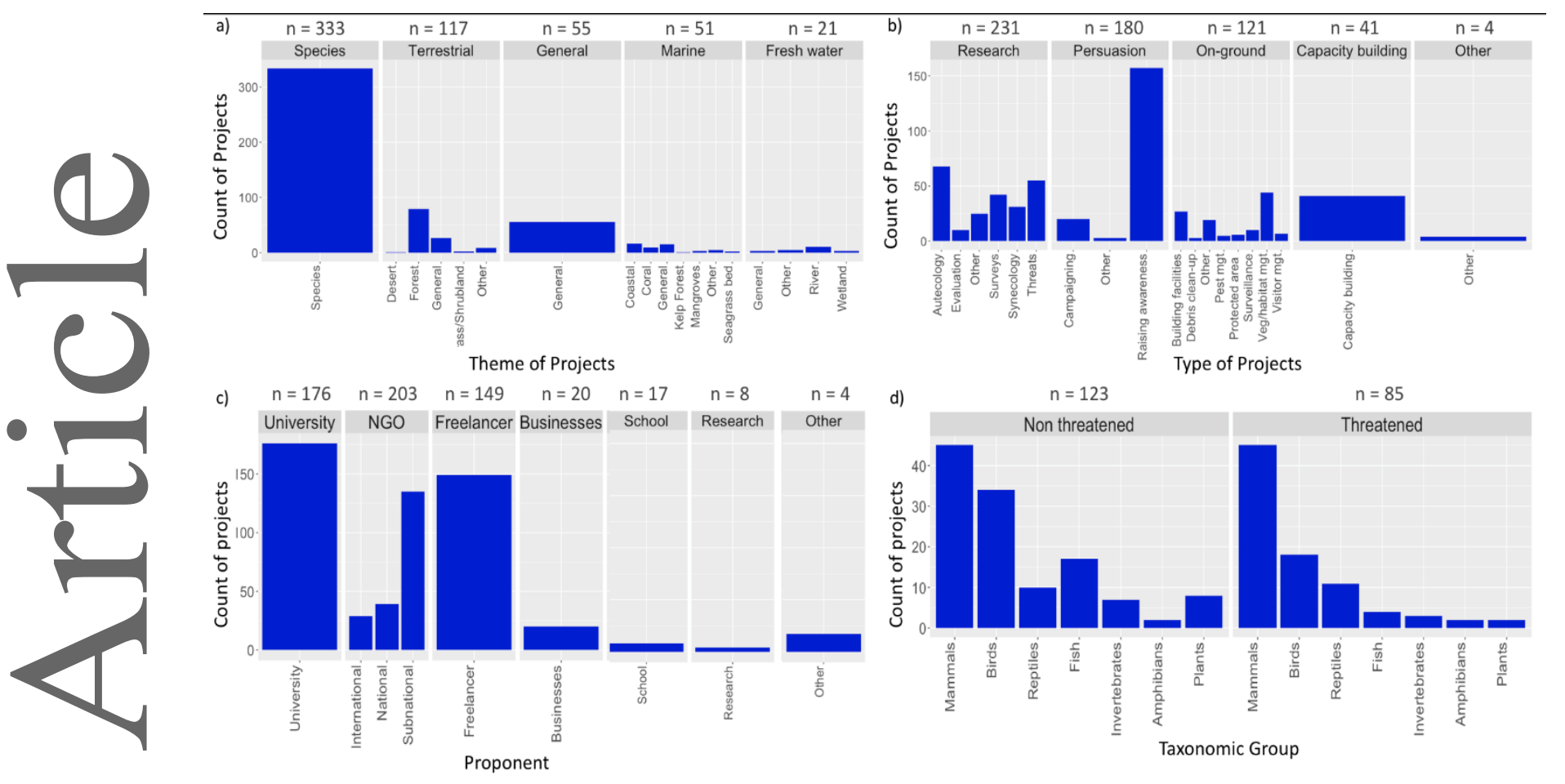

Figure 2. Conservation-focused projects according to: a) biodiversity realm, b) type of activity, c) type and scale of proponent, and d) number of focus taxa and their conservation status.

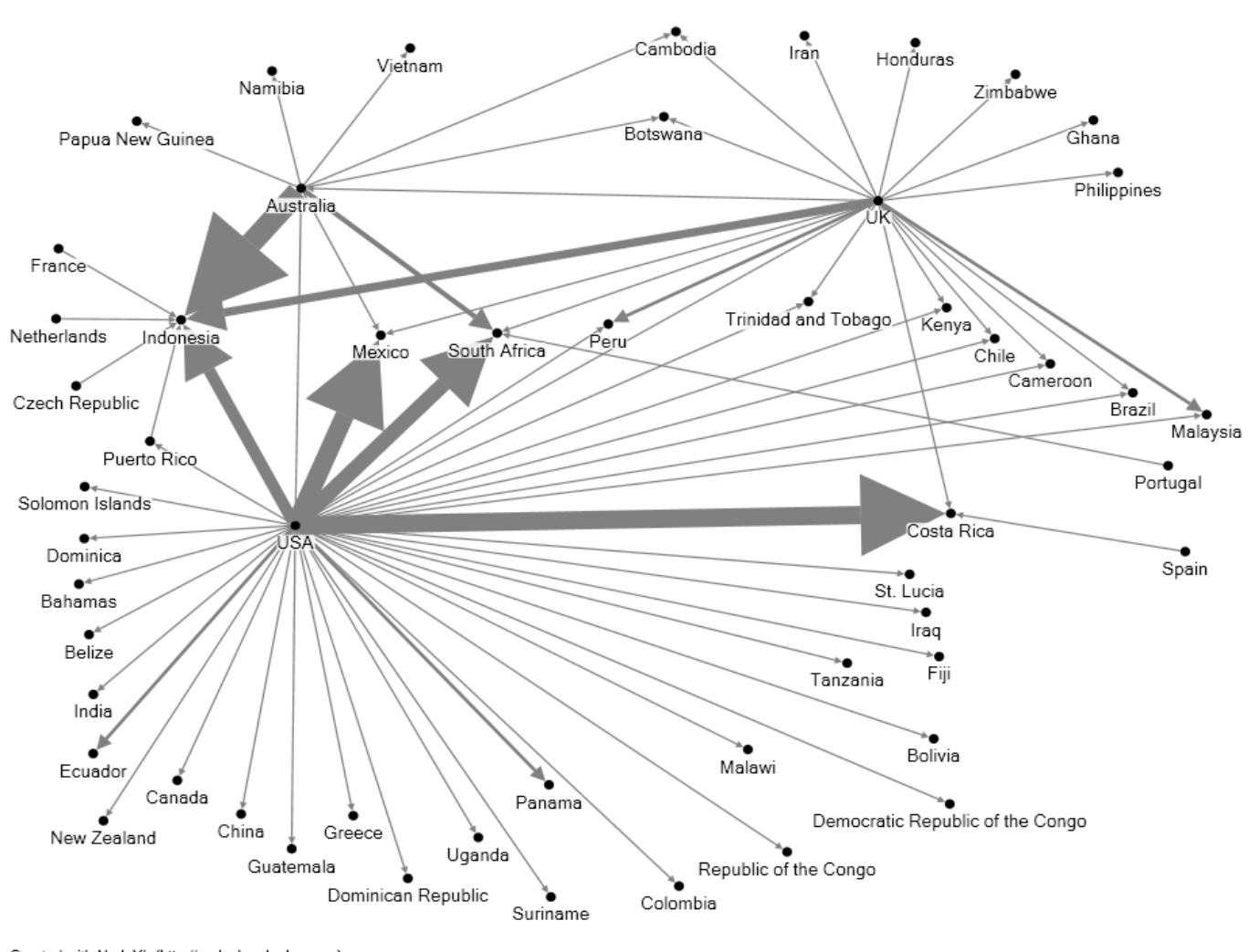

Figure 3. Weighted network of project flows for those countries with the highest outflows (i. e., USA, UK, and Australia) and inflows (i e., Indonesia, South Africa, Costa Rica, Mexico).

This article is protected by copyright. All rights reserved. 